\title{
ANDRAGOGO ORGANIZATORIAUS VAIDMUO TOBULINANT PEDAGOGŲ KVALIFIKACIJĄ
}

\author{
Nomeda Skliuderienè, Gitana Tolutienè \\ Klaipedos universitetas
}

\begin{abstract}
Anotacija
Siekiant išanalizuoti ir pagrịsti andragogo organizatoriaus vaidmenį tobulinant pedagogų kvalifikaciją, atskleidžiama pedagogų nuolatinio tobulinimosi ir andragogo organizatoriaus profesionalumo svarba, išryškinamos teigiamos pedagogų kvalifikacijos tobulinimo ir andragogo organizatoriaus veiklos sąsajų pusès bei problemos. Pirmoje straipsnio dalyje aptariama pedagogų kvalifikacijos tobulinimo samprata, ją pagrindžiant profesionalumo, profesionalizacijos aspektais, atskleidžiamas andragogo organizatoriaus veiklos ịvairialypiškumas, daugiafunkcionalumas tobulinant pedagogu kvalifikaciją. Antroje dalyje analizuojami švietimo dokumentai, reglamentuojantys pedagogų kvalifikacijos tobulinimo ir andragogu profesinę veiklą, apžvelgiama pedagogų kvalifikacijos tobulinimo būklè, atlikti tyrimai ir andragogo profesinès veiklos pripažinimas Lietuvoje. Šio straipsnio teorinị naujumą ir reikšmingumą atskleidžia pagrịsta pedagogų kvalifikacijos tobulinimo samprata, atskleistas andragogo veiklos ịvairialypiškumas ir daugiafunkcionalumas, ịrodyta andragogo organizatoriaus profesionalumo reikšmè, siekiant užtikrinti pedagogų kvalifikacijos tobulinimo kokybę. PAGRINDINIAI ŽODŽIAI: andragogas organizatorius, profesionalumas, profesionalizacija, pedagogas, kvalifikacija, tobulinimas.
\end{abstract}

\begin{abstract}
The importance of constant improvement of teachers and andragogue organiser's professionalism is revealed, advantages and issues of the link between teachers' qualification development and andragogue organiser's activity is highlighted to analyse and justify the andragogue organiser's role in the sphere of teachers' qualification development. The first part of the article discusses the conception of teachers' qualification development based on the aspects of professionalism, reveals diversity of andragogue organiser's activities and multi-functionality in the sphere of teachers' qualification development. The second part of the article analyses educational documents that regulate teachers' development activity and andragogues' professional activity, reviews the state of teachers' qualification development, carried out research and recognition of andragogue's professional activity in Lithuania. Justified conception of teachers' qualification development, revealed diversity and multi-functionality of andragogue's activities and proven importance of andragogue organiser's professionalism to ensure the quality of teachers' qualification reveals theoretical novelty and significance of this article. KEY WORDS: andragogue organizer, professionalism, professionalization, pedagogue, qualification, development.
\end{abstract}

DOI: http://dx.doi.org/10.15181/tbb.v79i3.1891

\section{Ivadas}

Remiantis pastarujų metų kvalifikacijos tobulinimo renginių statistika Lietuvoje, kai daugèja renginių mokyklų bendruomenėms, komandoms, galima teigti, kad mokyklų bendruomenės suvokia gebėjimo veikti išvien svarbą. Mokymasis 
komandoje - vienas iš besimokančios organizacijos bruožų. Lietuvoje kuriamo ir kitose šalyse egzistuojančio pedagogų kvalifikacijos tobulinimo (toliau - PKT) modelio kontekste, kai PKT turi atliepti ne tik paties kvalifikacijos tobulinimo, bet ir ugdymo įstaigos prioritetus bei veiklos tobulinimo kryptis, individualių ir kolektyvinių kompetencijų dermé gali būti traktuojama ne tik kaip sẻkmingo bendravimo ir bendradarbiavimo sąlyga, bet ir kaip vienas iš organizacijos tikslų. B. Jatkauskienė (2013) cituoja P. Corn'ą, kurio teigimu, mokytojų kompetencija yra kolektyvinė. Iš mokytojų kolektyvo (visos mokyklos, visos institucijos) tikimasi kompetentingumo. Nereikètų to tikètis tik iš mokytojo, ypač jo profesinès karjeros pradžioje: mokytojas turès mokytis visos profesinès karjeros metu, išlaikyti ,apetitą“ naujoms žinioms ir intelektiniam smalsumui. Jei jis pats to neturès, negalès to perduoti ir savo mokiniams. Kalbant apie PKT, pabréžiama, kad kvalifikacijos tobulinimas nuosekliai pratęsia pedagogo rengimą, pradètą aukštojoje mokykloje, ir turi trukti visą profesinès veiklos laikotarpi. Pedagogui keliami reikalavimai akcentuoja, kad jis turi ne tik gerai išmanyti savo dalyką, bet ir turèti atitinkamas asmenines savybes. Taigi jo veiklos sritis ir atsakomybe išplečiama, pradedant dalyko programos perteikimu mokiniui ir baigiant individualiu požiūriu ir veikimu konkrečiose profesinėse situacijose. PKT reglamentuojantys dokumentai (LR Švietimo ịstatymas, 2011; Valstybès švietimo strategijos 2013-2022 metų nuostatos, 2013; PKT koncepcija, 2012; Reikalavimų mokytojų kvalifikacijai aprašas, 2014 ir kt.) suteikia galimybę pedagogui tobulinti tiek individualius, tiek švietimo ịstaigos ar nacionalinius PKT poreikius. O organizuojant PKT procesą svarbiausias vaidmuo tenka andragogui organizatoriui, jo profesionalumui, ịvaldant edukacinę, vadybinę, tiriamąą veiklos sritis.

R. M. Andriekienè (2011) teigia, kad andragogo organizatoriaus pagrindinè veikla suaugusiųjų švietimo srityje skirstoma ị vidinę (savo institucijos konsultavimą) ir išorinę (kursų užsakovų konsultavimą), ir pabrèžia, jog jam keliama vis daugiau naujų reikalavimų, nors neaišku, kaip ir kokie jo atliekami vadybiniai vaidmenys daro didžiausią ịtaką praktinèje veikloje bendradarbiaujant visiems suaugusiujjų švietimo proceso veikejams: besimokantiesiems, andragogui organizatoriui, lektoriui, organizacijos administracijai ir kt. Andragogo organizatoriaus veikla pernelyg sudètinga, kad būtų galima visoms suaugusiujų švietimo institucijoms taikyti tas pačias nuostatas ar instrukcijas. Mokymosi aplinkų plètra, jų tipų gausejjimas andragogo organizatoriaus veiklą daro ypač priklausomą nuo konkrečioje institucijoje įsivyravusios suaugusiųjų švietimo strategijos, todèl šios veiklos reguliavimas yra suaugusiujų švietimo institucijos apsisprendimas. Kalbant apie PKT, svarbu pagrịsti andragogo, atitinkančio visas profesionalo savybes, svarbą. Ypač tai svarbu andragogo profesijos pripažinimo kontekste. Mokytojo profesija yra seniai pripažinta, anot D. Goode, dar 1960 metais, ji atitinka pagrindines profesijos charak- 
teristikas: mokytojams būdingas biurokratinis legitimizuotas statusas, tam tikros atliekamos funkcijos ir vaidmenys, bendras profesinis tapatumas bei vertybès. Tuo tarpu andragogų profesinè veikla, nors ir stebimos pastangos ją socialiai bei teisiškai pripažinti, menkinama ir neigiama realybejje (Andriekienè, 2011). Nors 2013 m. spalio 22 d. švietimo ir mokslo ministras patvirtino Andragogo profesinès veiklos aprašą, kuriame apibrèžta andragogo veiklos paskirtis, tikslai, uždaviniai ir kompetencijos, tačiau andragogo profesija ị Lietuvos profesijų klasifikatorių dar neittraukta. Todèl, nesant Lietuvoje andragogo pareigybès, galima kalbèti tik apie atliekamus profesinius vaidmenis, tarp jų ir andragogo organizatoriaus.

Visa tai suponuoja probleminius klausimus: kokia andragogo organizatoriaus profesionalumo reikšmė, siekiant užtikrinti PKT kokybę? Kokị vaidmenị pedagogo veiklos efektyvumui turi andragogas profesionalas, organizuojantis PKT procesą?

Straipsnio tikslas : išanalizuoti ir pagrịsti andragogo organizatoriaus vaidmeni tobulinant pedagogo kvalifikaciją.

Uždaviniai: 1) išanalizuoti PKT sampratą; 2) atskleisti andragogo organizatoriaus atliekamus vaidmenis, funkcijas, kompetencijas tobulinant pedagogo kvalifikaciją; 3) išnagrinèti LR teisès aktus, reglamentuojančius PKT ir andragogo profesinę veiklą.

Metodai: 1) mokslinès literatūros analizè, siekiant atskleisti pedagogų nuolatinio tobulinimosi ir andragogo organizatoriaus profesionalumo svarbą; 2) dokumentų analizè, siekiant išryškinti PKT ir andragogo organizatoriaus veiklos sąsajų teigiamas puses bei problemas.

\section{Teorinès pedagogų kvalifikacijos tobulinimo ir andragogo organizatoriaus vaidmens įžvalgos}

Pedagogų kvalifikacijos tobulinimo samprata ir jos pagrịstumas profesionalumo, profesionalizacijos aspektais. PKT koncepcijoje (2012) kompetencijos sąvoka derintina su žodžiais igyjama, ugdoma ir vartotina tiek bendrajam profesinių gebejjimų lygiui, tiek paskiriems gebejjimams atlikti profesines užduotis, veikti profesineje srityje apibūdinti; kvalifikacijos sąvoka derintina su žodžiais tobulinama, pripažistama, formalizuojama, reikalaujama ir vartotina dokumentais patvirtintai bei su profesine karjera siejamai kompetencijų ir patirties visumai apibūdinti. Koncepcijoje aptariama procesų ir priemonių visuma vadinama pedagogu kvalifikacijos tobulinimu, o paties pedagogo veikla siekiant igyti nauju ar aukštesnių kompetencijų - profesiniu tobulinimusi. Pastarojo samprata remiasi keliomis kertinėmis nuostatomis (Villegas-Reimers, 2003): 1) mokytojai yra aktyvūs besimokantieji; 2) mokosi nuolat; 3) mokymai vyksta konkrečioje aplinko- 
je; 4) profesinis tobulinimasis yra neatsiejama švietimo kaitos dalis; 5) mokytojai yra reflektuojantys praktikai; 6) profesinis tobulinimas vyksta bendradarbiaujant; 7) jis kinta, atsižvelgiant ị aplinką, kontekstą.

Analizuojant mokslinę literatūrą, formuojasi požiūris, kad PKT tikslas yra siekti meistriškumo savo srityje, t. y. tapti pedagogu profesionalu. Kaip teigia A. L. Strauss'as (1992), mokytojų profesionalumas ugdomas per visą jų išsimokslinimo procesą, o tobulinamas - visos profesinès karjeros laikotarpiu. A. Amrein'o (2006) teigimu, neužtenka tik kalbèti apie kokybišką ir rezultatyvią mokytojo veiklą, remiantis vien turimu diplomu, profesinių kompetencijų vertinimu, patirtimi, turimais gebejjimais ar veiklos būdais. Siekiant pagerinti ugdymo kokybę, reikia siekti didesnio mokytojų veiklos rezultatyvumo. Rezultatyviais mokytojais, T. Anderson'o (2004) teigimu, laikomi tie, kurie pasiekia savo ir kitų asmenų numatytus tikslus (Jatkauskienè, 2013).

Turint omenyje tai, kad PKT esmè yra patobulintų kompetencijų panaudojimas profesineje veikloje, t. y. ugdymo procese, o jų laukiamas pritaikymo rezultatas yra geresni mokinių pasiekimai, svarbu gebeti kompetencijas panaudoti ten, kur reikia. G. Le Boterf'as (2010) tai vadina kompetencijų perkèlimu, jo teigimu, kiekvienas iš mūsų yra girdèjęs kalbant ir žino, kad patirtị turintis profesionalas perkelia ar perteikia savo kompetencijas. Ugdytojai susirūpinę tuo, kad mokantis igytos žinios būtų perkeltos ir pritaikytos veiklos situacijoje. Pageidautina, kad profesionalas gebėtų ị ịvairias veiklos situacijas perkelti tai, ką jis moka atlikti konkrečioje situacijoje.

Kaip teigia A. M. Juozaitis (2008), remdamasis P. Jarviu (2001), mokymasis yra svarbi kiekvieno profesionalo veiklos dalis, todèl jis nuolat privalo dalyvauti profesionalizacijos veikloje. Profesionalumas, anot A. Pollard'o (2002), tai vertybiškai orientuota veikla, kai asmeniniai kiekvieno darbuotojo įsipareigojimai susipina su jo profesiniu vaidmeniu. Mokslininkai (Jatkauskienè ir kt., 2010) pabrèžia, kad profesionalizacija reiškia specialių žinių, mokẻjimų ir ịgūdžių ịgijimą pouniversitetinès praktikos metu, nuolatinị kvalifikacijos tobulinimą, numatytą įstatymų, siekiant gilinti ir tobulinti igytas žinias bei mokantis jas pritaikyti praktiškai. Arba, kaip nurodyta Tarptautinių žodžių žodyne (2008), profesionalizacija - tai profesijos ịvaldymas, specializavimasis kurioje nors srityje, perejimas ị profesionalų kategoriją. Profesionalizacija, anot H. Siebert'o (2007), - tai procesas, vykstantis dviem lygiais, kurie tarpusavyje susiję. Tai profesinių, mokslo žinių, kurios suformuotų kompetentingos veiklos teorinị ir empirini pagrindą, kaupimas bei profesijos su jos specifinèmis kvalifikacijomis ir kompetencijomis pripažinimas. Taigi galima teigti, kad kvalifikacijos tobulinimas yra vienas iš profesionalizaci- 
jos elementų. Kadangi pedagogams išorès profesionalizacija (išskirtinio statuso reikalavimas, profesinio tapatumo formavimas ir kt.) nèra tiek aktuali, straipsnyje dèmesị kreipiame ị pedagogų vidaus profesionalizaciją (mokslo žinių kaupimą, kompetencijų ugdymą, kvalifikacijos tobulinimą), kuri pasireiškia profesiniu kompetentingumu. Pedagogų vidaus profesionalizaciją reglamentuoja LR teisès aktai, kurie numato PKT, kvalifikacinès kategorijos igijimo ir atestacijos tvarką, dalyvavimą metodinių būrelių veikloje, savianalizę, atliekamą kiekvienais mokslo metais, ir t. t.

Apibendrinant galima teigti, kad pedagogas visų pirma pats turi dalyvauti profesionalizacijos procese. Esant iššūkių ir reikalavimų kupiname profesinès veiklos sūkuryje, pedagogui tobulinant kvalifikaciją dažnai būtina kompetentinga pagalba, profesionalus jo kvalifikacijos etapo įvertinimas ir tikslingas nukreipimas toliau tobulèti.

Andragogo organizatoriaus vaidmens ịvairialypiškumas ir daugiafunkciškumas tobulinant pedagogų kvalifikaciją. Kalbant apie PKT numanomi du veikejjai - pedagogas ir andragogas. Kadangi suaugęs besimokantysis yra laikinas klientas, švietimo programose ieškantis tik to, ko reikia jo asmeniniams ar profesiniams siekiams igyvendinti, jo mokymosi procesui turètu vadovauti andragogas, nes, pasak Ph. Meirieu (2007), jis žino, išmano ir siūlo produktyviausią žinių ịijimo būdą (Jatkauskienè, 2013). Remiantis šiuo teiginiu, akivaizdu, kad andragogas turi būti tas asmuo, kuris, išmanydamas andragoginès veiklos technologijas, palengvintų pedagogo mokymosi procesą.

R. M. Andriekienè (2011) pabrěžia, kad šiandien kalbant apie nuolatinị suaugusiujjų švietimą akcentuojamas ne tiek lektoriaus, kiek andragogų analitikų (tyrèjų), organizatorių, konsultantų, patarèjų, vadybininkų, mentorių vaidmuo. Pabandę perkelti šiuos vaidmenis ị PKT sriti, matome, kad PKT formų spektrą papildančios naujos efektyvios mokymosi formos leidžia ir šioje srityje nustatyti įvairius mokymosi rezultatams reikšmingus andragogo vaidmenis. Ypač svarbus vaidmuo tenka PKT srityje dirbančiam andragogui. R. M. Andriekienè ir D. Martišauskienė (2013) teigia, kad siekiant kokybiškai teikti suaugusiujų švietimo paslaugas kinta ne tik andragogo vaidmenys, bet ir visa jo veikla, nukreipta ị kliento, besimokančiojo poreikius. Autoriai (Andriekienè, 2011; Zuzevičiūtè ir kt., 2008; Teresevičienè ir kt., 2006; Barkauskaite, 2006 ir kt.) akcentuoja, kad andragogas, siekdamas paslaugų kokybès, privalo išanalizuoti užsakovų poreikius, atlikti besimokančiujų asmeninių savybių, gebẻjimų, pomėgių, požiūrio ir kt. analizę, atsižvelgęs ị nustatytus poreikius ir ištirtą požiūrị, turimas žinias numatyti mokymosi kursų tikslą ir uždavinius, rengti programas. Tad didejjant reikalavimams ir konkurencijai, kintant besimokančiujų poreikiams ypač aktualus kliento pažinimas, paslaugų koky- 
bės valdymas. Kaip teigiama PKT koncepcijoje (2012), PKT sistema turi sudaryti palankias sąlygas ir kurti paskatas, kad PKT paslaugas būtu suinteresuotos teikti pirmiausia tos institucijos, kurios turi reikiamą patirtį, bazę ir kvalifikuotą personalą. Todèl svarbu, kad šių paslaugų teikimą koordinuotų andragogas profesionalas, turintis tiek teorinių žinių, tiek praktinę, analitinę patirtį.

Užsienio autorių (Buiskool ir kt., 2010) teigimu, suaugusiujų švietejjų profesionalų veiklos sritis sieja profesinès veiklos kompetencijos, kurios skaidomos i dvi dalis - bendrąsias ir savitąsias. Bendrosios kompetencijos yra svarbiausios, jų reikia, norint atlikti veiklas suaugusiųjų švietimo sektoriuje (mokymo, konsultavimo, vadybinès ar administracinès veiklos): pirmos trys (A1-A3) apima profesionalumo lauką, o keturios paskutinès (A4-A7) yra pedagoginès / didaktinès kompetencijos (1 lentelè).

1 lentelè. Suaugusiujų švietėjų profesionalų bendrosios kompetencijos

(Buiskool ir kt., 2010)

\begin{tabular}{|c|c|c|}
\hline $\begin{array}{l}\text { Eil. } \\
\text { Nr. }\end{array}$ & Kompetencija & Apibūdinimas \\
\hline A1 & $\begin{array}{l}\text { Savo praktikos, mokymosi } \\
\text { ir asmeninio tobulejjimo } \\
\text { apmąstymo, vertinimo }\end{array}$ & $\begin{array}{l}\text { Gebejjimas kritiškai mąstyti, ivertinti savo mo- } \\
\text { kymosi poreikius, organizuoti ir valdyti savo } \\
\text { mokymosi procesą }\end{array}$ \\
\hline A2 & $\begin{array}{l}\text { Bendravimo ir } \\
\text { bendradarbiavimo su } \\
\text { besimokančiais suaugusiaisiais, } \\
\text { kolegomis bei suinteresuotomis } \\
\text { šalimis }\end{array}$ & $\begin{array}{l}\text { Gebejjimas bendrauti su besimokančiais suau- } \\
\text { gusiaisiais, bendradarbiais ir suinteresuotomis } \\
\text { šalimis, dirbti komandoje, bendradarbiauti su } \\
\text { bendradarbiais, keistis žiniomis ir patirtimi, nu- } \\
\text { sakyti problemą ir ją spręsti }\end{array}$ \\
\hline A3 & $\begin{array}{l}\text { Suaugusiujų švietimo ịstaigos } \\
\text { struktūros plètros ir tobulinimo } \\
\text { bei profesinės praktikos, } \\
\text { isstaigos, sektoriaus, profesijos ir } \\
\text { visuomenès pokyčiu numatymo }\end{array}$ & $\begin{array}{l}\text { Gebèjimas prisiimti atsakomybę už ịstaigos, } \\
\text { sektoriaus ir profesijos plètrą bei tobulinimą, ge- } \\
\text { bèti bendrauti, derètis ir ieškoti problemų spren- } \\
\text { dimo būdų su suinteresuotomis šalimis }\end{array}$ \\
\hline A4 & $\begin{array}{l}\text { Savo dalyko srities patirties } \\
\text { ir galimų mokymo išteklių } \\
\text { naudojimo }\end{array}$ & $\begin{array}{l}\text { Gebejjimas panaudoti dalyko ar praktikos žinias, } \\
\text { pasirinkti tinkamus mokymo šaltinius, pasinau- } \\
\text { doti besimokančių suaugusiujų mokymosi šalti- } \\
\text { niais, motyvuoti suaugusiuosius mokytis sava- } \\
\text { rankiškai }\end{array}$ \\
\hline A5 & $\begin{array}{l}\text { Ivairių mokymo metodų, } \\
\text { formų ir būdų taikymo, } \\
\text { naujų galimybių žinojimo ir } \\
\text { elektroninių igūdžių }\end{array}$ & $\begin{array}{l}\text { Gebėjimas mokymo procese taikyti mokymo } \\
\text { metodus, formas ir būdus, IKT bei žiniasklaidos } \\
\text { priemones, individualiai besimokančiam suau- } \\
\text { gusiajam ir grupei valdyti mokymo procesą }\end{array}$ \\
\hline
\end{tabular}




\begin{tabular}{|c|c|c|}
\hline $\begin{array}{l}\text { Eil. } \\
\text { Nr. }\end{array}$ & Kompetencija & Apibūdinimas \\
\hline A6 & $\begin{array}{l}\text { Besimokančių suaugusiujų } \\
\text { mokymosi igalinimo ir jų, kaip } \\
\text { visapusiškai nepriklausomǔ, } \\
\text { visą gyvenimą besimokančių } \\
\text { asmenų, palaikymo }\end{array}$ & $\begin{array}{l}\text { Gebejjimas motyvuoti, skatinti ir igalinti besi- } \\
\text { mokančius suaugusiuosius kalbèti apie mokymo } \\
\text { proceso aktualumą, sukurti skatinančią moky- } \\
\text { mosi aplinką }\end{array}$ \\
\hline A7 & $\begin{array}{l}\text { Darbo su besikeičiančiomis ir } \\
\text { heterogeninemis grupemis, kurių } \\
\text { skirtingi mokymosi poreikiai ir } \\
\text { turima patirtis, motyvacija }\end{array}$ & $\begin{array}{l}\text { Gebėjimas atpažinti besimokančiujų išsilavini- } \\
\text { mo lygi, valdyti heterogenines grupes, analizuo- } \\
\text { ti besimokančiujuc elgesį, atpažinti problemas ir } \\
\text { galimus konfliktus bei gebėti jų išvengti }\end{array}$ \\
\hline
\end{tabular}

Minètų autorių teigimu, savitosios kompetencijos būtinos atliekant tam tikrą specifinę veiklą (pvz., sprendžiant administracinius klausimus). Jos būtinos ne visiems profesionalams, dirbantiems suaugusiujjų švietimo srityje. Jos skirstomos ị tas, kurios tiesiogiai susijusios su mokymo procesu (B1-B6), - tai mokymas ar konsultavimas, ir netiesiogiai susijusios su mokymosi procesu ar jo palaikymu (B7-B12), - tai valdymas ir administracinè parama (2 lentelè).

2 lentele. Savitosios kompetencijos, būtinos suaugusiųjų švietimo srityje

(Buiskool ir kt., 2010)

\begin{tabular}{|c|c|c|}
\hline $\begin{array}{l}\text { Eil. } \\
\text { Nr. }\end{array}$ & Kompetencija & Apibūdinimas \\
\hline B1 & $\begin{array}{l}\text { Besimokančių suaugusiujų } \\
\text { ankstesnès patirties, mokymosi } \\
\text { poreikių, motyvacijos, } \\
\text { vertinimo }\end{array}$ & $\begin{array}{l}\text { Gebėjimas vertinti ankstesnes besimokančio } \\
\text { suaugusiojo patirtis, mokymosi poreikius, mo- } \\
\text { tyvaciją ir pageidavimus, ižvelgti ir panaudoti } \\
\text { besimokančio suaugusiojo patirtị ir žinias, kaip } \\
\text { mokymo išteklius }\end{array}$ \\
\hline B2 & $\begin{array}{l}\text { Suaugusiųjų mokymo proceso } \\
\text { organizavimo }\end{array}$ & $\begin{array}{l}\text { Gebèjimas parinkti suaugusiųų mokymui(si) } \\
\text { tinkamą mokymosi stilių, didaktinius metodus ir } \\
\text { turini, planuoti mokymo procesą ir, atsižvelgiant } \\
\text { i individualų besimokantị suaugusiji ar jų grupę, } \\
\text { jị pritaikyti }\end{array}$ \\
\hline B3 & $\begin{array}{l}\text { Besimokančių suaugusiujų } \\
\text { mokymosi proceso lengvinimo }\end{array}$ & $\begin{array}{l}\text { Gebèjimas taikyti įvairias mokymo formas, meto- } \\
\text { dus ir būdus, dirbti su heterogeninemis grupèmis, } \\
\text { skatinti besimokantijị mokytis savarankiškai, val- } \\
\text { dyti mokymo procesą, pririekus, keisti mokymo } \\
\text { strategiją }\end{array}$ \\
\hline B4 & $\begin{array}{l}\text { Nuolatinio suaugusiujų } \\
\text { mokymosi proceso stebejjimo ir } \\
\text { vertinimo }\end{array}$ & $\begin{array}{l}\text { Gebejjimas nuosekliai stebèti ir vertinti besimo- } \\
\text { kančių suaugusiujų mokymosi procesą, pasirink- } \\
\text { tą mokymosi strategiją, naudojamus mokymosi } \\
\text { išteklius, siekiant juos patobulinti }\end{array}$ \\
\hline
\end{tabular}




\begin{tabular}{|c|c|c|}
\hline $\begin{array}{l}\text { Eil. } \\
\text { Nr. }\end{array}$ & Kompetencija & Apibūdinimas \\
\hline B5 & $\begin{array}{l}\text { Patarimo karjeros, gyvenimo, } \\
\text { tolesnio lavinimo klausimais ir } \\
\text { profesionalios pagalbos teikimo }\end{array}$ & $\begin{array}{l}\text { Gebejjimas patarti, konsultuoti karjeros, gyveni- } \\
\text { mo, tolesnio lavinimosi klausimais, gebėti, pasi- } \\
\text { naudojus testais, surinkti dominančią informaciją } \\
\text { apie besimokantį suaugusiji }\end{array}$ \\
\hline B6 & $\begin{array}{l}\text { Studijų programų planavimo ir } \\
\text { rengimo }\end{array}$ & $\begin{array}{l}\text { Gebejjimas planuoti ir kurti studiju programas, } \\
\text { atsižvelgiant ị suaugusiujų mokymo teoriją ir be- } \\
\text { simokančių suaugusiujų poreikius, naudoti ịverti- } \\
\text { nimo įrankius }\end{array}$ \\
\hline B7 & Finansinių išteklių valdymo & $\begin{array}{l}\text { Gebejjimas valdyti finansinius išteklius, duome- } \\
\text { nis, ieškoti papildomų pajamų šaltinių, ịvertinti } \\
\text { ir apibūdinti suaugusiujų mokymosi socialinę ir } \\
\text { ekonominę naudą }\end{array}$ \\
\hline B8 & $\begin{array}{l}\text { Žmonių išteklių valdymo } \\
\text { kompetencija }\end{array}$ & $\begin{array}{l}\text { Gebejjimas suburti darbuotojų grupes, išsirinkti } \\
\text { tinkamus darbuotojus, jiems pasiūlyti tinkamus } \\
\text { profesinio tobulinimosi kursus. Lyderio savybès }\end{array}$ \\
\hline B9 & $\begin{array}{l}\text { Suaugusiujų mokymosi ịstaigos } \\
\text { valdymo ir vadovavimo bei } \\
\text { teikiamų kursų kokybės } \\
\text { valdymo }\end{array}$ & $\begin{array}{l}\text { Gebejjimas valdyti ir vadovauti suaugusiųjų švie- } \\
\text { timo ịstaigai, igyvendinti atskaitomybès sistemą } \\
\text { (kokybès vadyba), suprasti ir atsižvelgti ị visuo- } \\
\text { menės ir suaugusiųų mokymosi poreikius }\end{array}$ \\
\hline $\mathrm{B} 10$ & $\begin{array}{l}\text { Viešujų ryšių ir rinkodaros } \\
\text { kompetencija }\end{array}$ & $\begin{array}{l}\text { Gebejjimas taikyti ịvairias viešujų ryšių ir rinko- } \\
\text { daros strategijas, bendrauti su suinteresuotomis } \\
\text { šalimis, išorès partneriais ir organizacijomis, } \\
\text { ižvelgti naujų programų galimybes }\end{array}$ \\
\hline B11 & $\begin{array}{l}\text { Administracinių klausimų } \\
\text { sprendimo }\end{array}$ & $\begin{array}{l}\text { Gebejimas spręsti administracinius klausimus, } \\
\text { dirbti su administracinemis programomis, infor- } \\
\text { muoti ir padèti besimokantiems suaugusiesiems } \\
\text { bei andragogams }\end{array}$ \\
\hline B12 & $\begin{array}{l}\text { Paramos besimokantiems } \\
\text { suaugusiesiems ir } \\
\text { andragogams, naudojantiems } \\
\text { IKT paremtas mokymosi } \\
\text { aplinkas }\end{array}$ & $\begin{array}{l}\text { Gebejimas projektuoti, kurti, igyvendinti moky- } \\
\text { mosi aplinkas naudojant IKT, padeti tas moky- } \\
\text { mosi aplinkas naudojantiems ir jose dirbantiems } \\
\text { andragogams, besimokantiems suaugusiesiems, } \\
\text { ịvertinti IKT paremtos mokymosi aplinkos veiks- } \\
\text { mingumą }\end{array}$ \\
\hline
\end{tabular}

Tie patys autoriai (Buiskool ir kt., 2010) suaugusiųų švietejų kompetencijos struktūroje skiria trylika veiklos, kuri atliekama suaugusiųų švietimo įstaigoje (ne tik su mokymu susijusios veiklos), sričių (3 lentelè). 
3 lentele. Suaugusiujų švietimo ịstaigos veiklos sritys (Buiskool ir kt., 2010)

\begin{tabular}{|c|c|}
\hline Veiklos sritis & Apibūdinimas \\
\hline $\begin{array}{l}\text { Mokymosi poreikių } \\
\text { vertinimas }\end{array}$ & $\begin{array}{l}\text { Besimokantys suaugusieji turi patirties, žinių, todèl svarbu nustaty- } \\
\text { ti ir ịvertinti įvairius jų poreikius ir galimybes, ankstesnę mokymosi } \\
\text { patirtị }\end{array}$ \\
\hline Kursų rengimas & $\begin{array}{l}\text { Atsižvelgiant ị ịvairius besimokančių suaugusiųjų mokymosi po- } \\
\text { reikius, lygius ir pan., numatyti ir organizuoti mokymosi procesą, } \\
\text { nustatyti mokymosi išteklius ir tinkamus metodus (įskaitant IKT } \\
\text { infrastruktūrą) }\end{array}$ \\
\hline $\begin{array}{l}\text { Mokymo(si) } \\
\text { lengvinimas }\end{array}$ & $\begin{array}{l}\text { Igalinti, motyvuoti, skatinti besimokančius suaugusiuosius moky- } \\
\text { tis, kurti pozityvią mokymosi aplinką, suprantamą mokymo(si) tu- } \\
\text { rinį ir pritaikyti ji besimokančių suaugusiujų poreikiams bei gebè- } \\
\text { jimams, (i)vertinti mokymosi procesą ir besimokančių suaugusiujų } \\
\text { pažangą, orientuotis i aktualias suaugusiųjų švietimo sektoriuje } \\
\text { vyraujančias tendencijas, tobulinti kursus, siekiant pagerinti moky- } \\
\text { mosi proceso kokybę }\end{array}$ \\
\hline $\begin{array}{l}\text { Stebejjimas ir } \\
\text { vertinimas }\end{array}$ & Vertinti mokymosi proceso kontekstą, pati procesą ir rezultatus \\
\hline $\begin{array}{l}\text { Konsultavimas ir } \\
\text { pagalba }\end{array}$ & Teikti pagrindinę ir su karjera susijusią informaciją, konsultacijas \\
\hline $\begin{array}{l}\text { Programų } \\
\text { tobulinimas }\end{array}$ & $\begin{array}{l}\text { Modulio ir programos lygmeniu kurti mokymo turinį, atsižvelgiant } \\
\text { ị besimokančių suaugusiujų padètị, kurti lanksčias programas, t. y. } \\
\text { nuolatinės, ištęstinės studijos, moduliai, nuotolinis ar mišrusis mo- } \\
\text { kymasis ir pan. }\end{array}$ \\
\hline Finansų valdymas & $\begin{array}{l}\text { Valdyti išteklius, sudaryti ir administruoti biudžetą, rengti paraiš- } \\
\text { kas, siekiant gauti finansavimą, nustatyti išmokas, įmokas }\end{array}$ \\
\hline $\begin{array}{l}\text { Žmonių išteklių } \\
\text { valdymas }\end{array}$ & $\begin{array}{l}\text { Valdyti pedagoginị ir kitą personalą, stebėti ir vertinti darbo ko- } \\
\text { kybę, planuoti, organizuoti profesinị tobulinimą (kompetencijų to- } \\
\text { bulinimas, perkvalifikavimas, stažuotès, kursai ir pan.), informuoti } \\
\text { darbuotojus apie mokymosi galimybes }\end{array}$ \\
\hline Valdymas & $\begin{array}{l}\text { Prižiūrèti mokymo(si) aplinkas, stebèti ir vertinti programas, jas to- } \\
\text { bulinti, vertinti esamų ir naujų programų paklausą, kurti ir palaikyti } \\
\text { ryšius su suinteresuotomis šalimis (užsakovais, kursų teikejjais ir } \\
\text { pan.), užtikrinti kokybę, domètis teisès aktais ir reglamentais, igy- } \\
\text { vendinti jų pakeitimus }\end{array}$ \\
\hline $\begin{array}{l}\text { Rinkodara ir } \\
\text { viešieji ryšiai }\end{array}$ & $\begin{array}{l}\text { Vertinti esamų ir naujų programų pasiūlą bei paklausą, kurti ir pa- } \\
\text { laikyti santykius su suinteresuotomis šalimis, partneriais }\end{array}$ \\
\hline $\begin{array}{l}\text { Administracinè } \\
\text { parama }\end{array}$ & $\begin{array}{l}\text { Ivairios administracinės veiklos (priimti skambučius, užsakyti kur- } \\
\text { sus, surinkti ir saugoti informaciją apie besimokančius suaugusiuo- } \\
\text { sius, jų pažangą ir pan.), informavimas, pagalba besimokantiesiems } \\
\text { ir darbuotojams sprendžiant administracinius klausimus }\end{array}$ \\
\hline
\end{tabular}




\begin{tabular}{|l|l|}
\hline \multicolumn{1}{|c|}{ Veiklos sritis } & \multicolumn{1}{c|}{ Apibūdinimas } \\
\hline IKT palaikymas & $\begin{array}{l}\text { Prisidėti prie IKT grindžiamų ir mišrių studijų programų kūrimo, } \\
\text { teikti IKT paremtas programas, skatinti, organizuoti vertinimą vir- } \\
\text { tualioje aplinkoje, sukurti ir administruoti švietimo ịstaigos inter- } \\
\text { neto puslapi }\end{array}$ \\
\hline Bendrosios veiklos & $\begin{array}{l}\text { Tobulinant mokymo procesą dirbti su kitomis švietimo įstaigomis, } \\
\text { verslo įmonėmis ir besimokančiaisiais, skleisti gerąą patirti, pa- } \\
\text { remti, padeti jauniems andragogams }\end{array}$ \\
\hline
\end{tabular}

Apibendrinant galima teigti, kad nepaisant andragogo atliekamo vaidmens PKT srityje, visada išlieka svarbus profesionalumas. PKT veiksmingumas priklausys nuo andragogo organizatoriaus teikiamų paslaugų kokybės: pradedant užsakovo poreikių tyrimu, baigiant mokymo kurso programos praktinio pritaikomumo užtikrinimu. Akivaizdu, kad andragogas organizatorius turi disponuoti kompleksu atitinkamų asmeninių savybių ir specifinių profesinių žinių.

\section{Pedagogų kvalifikacijos tobulinimo ir andragogo profesinès veiklos teisinis reglamentavimas bei kaitos tendencijos}

Pedagogų kvalifikacijos tobulinimo teisinis reglamentavimas ir būklè Lietuvoje. PKT ịvairiais aspektais reglamentuoja daugiau kaip 50 ịvairaus lygio nacionalinių teisès aktų (įstatymų, Vyriausybės nutarimų, ministrų įsakymų, įskaitant švietimo ir mokslo ministro ịsakymu tvirtinamas programas). Pastaraisiais metais nacionaliniu lygmeniu PKT sistemai tobulinti ir plètoti skiriamas ypač didelis dèmesys. Didžiausia ŠMM pavaldi švietimo pagalbą mokiniui, mokytojui, mokyklai teikianti valstybinè švietimo įstaiga - Ugdymo plètotès centras (toliau - UPC) ŠMM užsakymu igyvendino I etapą ir tebevykdo II ir III projekto „PKT ir perkvalifikavimo sistemos plètra“ etapus, kurių tikslas - sudaryti PKT ir perkvalifikavimo sąlygas, sukurti modelį, kuris apimtų visas pedagogo karjeros stadijas, kryptis ir galimybes, derètų su mokyklų vertinimo ir finansavimo principais bei švietimo sistemoje vykstančiais kaitos procesais. Projekto uždaviniai: organizuoti pedagogu perkvalifikavimo studijas, sukurti veiksmingą PKT modelị ir išbandyti naujas PKT formas. Vykdant pirmaji projekto etapą atlikta Lietuvos PKT sistemos analizè (2011), sukurtas ir su ŠMM suderintas PKT modelis (2012). Jis kurtas viešujų konsultacijų principu, į jo rengimą ir svarstymą ịtraukiant ịvairias interesų grupes. Lietuvos švietimo centrai, teikiantys pedagogams kvalifikacijos tobulinimo paslaugas, yra šio projekto partneriai ir aktyviai dalyvauja jo igyvendinimo veiklose. I etape igyvendintos naujos PKT formos: minimokymai atrinktų mokyklų bendruomenėms, facilitato- 
rių ir mokytojų patarèjų mokymai, supervizija. II etape ịgyvendintos profesinės kvalifikacijos tobulinimo modelyje numatytos būtinos priemonès, susijusios su pedagogo karjeros raida, paslaugų kokybės stebėsena bei švietimo konsultanto veiklos reglamentavimu.

Atlikus Lietuvos PKT sistemos analizę (2011), naudojant klasikinę SSGG matricą, îvardytos jos stiprybès, silpnybès, galimybès ir grèsmès (stiprybès ir silpnybės yra organizacijos, šiuo atveju - PKT, kaip veiklos srities viduje besireiškiančios problemos, gebėjimai [4 lentelè], o galimybès ir grèsmès - tai, kas veikia organizaciją, šiuo atveju - PKT, kaip veiklos sritį iš išorès [5 lentelè].

4 lentele. Lietuvos pedagogų kvalifikacijos tobulinimo sistemos stiprybės ir silpnybės (2011)

\begin{tabular}{|c|c|}
\hline \multicolumn{2}{|c|}{ Vidinė aplinka } \\
\hline Stiprybès & Silpnybès \\
\hline $\begin{array}{l}\text { 2. Decentralizuota PKT sistema, paslaugų } \\
\text { teikèjų ịvairovè } \\
\text { 3. Užtikrintas PKT paslaugų } \\
\text { prieinamumas: išplètotas mokytojų } \\
\text { švietimo centru tinklas regionuose, aiškios } \\
\text { centrų funkcijos } \\
\text { 4. PKT pasiūlos ịvairovè (formos, } \\
\text { priemonès, vieta ir pan.) } \\
\text { 5. Veikia lektorių sertifikavimo sistema } \\
\text { (parengta ŠDC, svarstyta ŠMM) } \\
\text { 6. Sukurti Pradedančiojo mokytojo } \\
\text { standarto pradmenys (ŠDC ir tarptautinės } \\
\text { komandos parengtas kompetencijų aprašas } \\
\text { iteiktas ŠMM) }\end{array}$ & $\begin{array}{l}\text { 1. PKT proceso organizavimas vyksta ne- } \\
\text { turint aiškaus vadybinio modelio, schemos } \\
\text { (labiau chaotiškai) } \\
\text { 2. Formalizuotas ir uždaras paslaugų verti- } \\
\text { nimas (nevertinama arba mažai vertinama } \\
\text { kokybè) } \\
\text { 3. PKT nesiorientuoja būtent i rezultatą } \\
\text { (klasės, mokyklos lygmeniu) } \\
\text { 4. Trumpalaikiai PKT renginiai, neturintys } \\
\text { ilgalaikio poveikio } \\
\text { 5. Mažai tarpusavyje derinami mokyklų ir } \\
\text { individualūs mokytojų poreikiai } \\
\text { 6. Mokytojai, mokyklos ir švietimo centrai } \\
\text { mažai dalijasi profesine patirtimi } \\
\text { 7. PKT suprantama siaurai (vyrauja domè- } \\
\text { jimasis desstomo dalyko tobulinimu, mažai } \\
\text { demesio skiriama naujovèms, kurios susiju- } \\
\text { sios su globaliais pokyčiais, visuomeninè- } \\
\text { mis tendencijomis) } \\
\text { 8. Mokyklos ir mokytojai ne visada gali } \\
\text { pasirinkti pageidaujamą PKT paslaugos } \\
\text { teikèją (jei pinigai - savivaldybès švietimo } \\
\text { centre) } \\
\text { 9. Informacijos apie PKT teikiamas paslau- } \\
\text { gas prieinamumas, išsamumas }\end{array}$ \\
\hline
\end{tabular}


5 lentelè. Lietuvos pedagogų kvalifikacijos tobulinimo sistemos galimybès ir grèsmès (2011)

\begin{tabular}{|c|c|}
\hline \multicolumn{2}{|c|}{ Išorinė aplinka } \\
\hline Galimybès & Grèsmès \\
\hline 1. Sukurta tarpusavyje derančių & 1. Nebus bendros PKT koncep \\
\hline & 2. ŠMM švietimo strategijoje nebus numatytas \\
\hline 2. PKT remsis valstybine švietimo & PKT kokybès vertinimas (nėra aiškių kokybès \\
\hline strategija & erijų, neaiškus tolesnis akredita- \\
\hline 3. Bus realiai pripažįstami ES & cijos sistemos likimas) \\
\hline prioritetai: kokybè, efektyvumas, & 3. Pedagoginès kvalifikacijos reikalavimai bus \\
\hline $\begin{array}{l}\text { tęstinis mokymasis, partnerystė, } \\
\text { mobilumas (orientacija ị ES stan }\end{array}$ & $\begin{array}{l}\text { nukreipti ne } \mathfrak{i} \text { kompetencijas, o } \mathfrak{i} \text { formalius rei- } \\
\text { kalavimus }\end{array}$ \\
\hline 4. Vykdant PKT bus orientuojamasi & 4. Nebus formalios ir neformalios veiksmų ko- \\
\hline & \\
\hline $\begin{array}{l}\text { kompetencijos aprašą, kaip svarbiausią } \\
\text { norminį dokumentą }\end{array}$ & $\begin{array}{l}\text { 5. Viešujų pirkimų ịstatymas bus nukreiptas ị } \\
\text { „pigią prekę“ (mažiausia kaina) }\end{array}$ \\
\hline
\end{tabular}

Lietuvos PKT sistemos analizès (2011) autoriai pateikè siūlymų, kuriomis kryptimis tobulinti PKT sistemą: 1) didinti PKT galimybes, parengiant strategiškai pagrįstą PKT koncepciją ir atnaujinant Mokytojo profesijos kompetencijų aprašą, kompetencijas siejant su mokytojo pedagogine kvalifikacija; 2) puoseleti esamas PKT sistemos stiprybes, dèmesị kreipiant ị būtinybę tobulinti šios sistemos viduje proceso organizavimo vadybinį modelị ir paslaugos vertinimą kaip kontekstualaus ir sisteminio proceso stebėseną; 3) PKT planuoti strategiškai visais lygmenimis (valstybè, savivaldybè, mokykla, mokytojas) pagal numatytus prioritetus ir sieti su pokyčiais ugdymo procese, kurie lemtų finansini skatinimą ir karjeros galimybes. Remiantis šiais siūlymais, sukurtas PKT modelis (2012), kuris atliepia švietimo sistemoje vykstančius kaitos ir Lietuvos mokymosi visą gyvenimą strategijos programos ịgyvendinimo procesus. Autorių (Dačiulytė, Dromantienè ir kt., 2011) teigimu, PKT proceso organizavimas turi būti susietas su ị rezultatą (mokinio pasiekimų gerinimą) orientuotu valdymu. Reikšmingą vaidmenį vaidina mokyklos vadovas, palaikantis ir skatinantis nuolatinị pedagogų siekị tobulèti, investuojantis ị mokyklą, kaip besimokančią organizaciją. Vertinimo sistemos centrinè ašis fokusuojama ties konkrečia praktine pedagogine veikla, t. y. asmeniniu lygmeniu orientuojamasi ị profesinị tobulejjimą, kompetencijų ugdymą, instituciniu - i konkrečią pamoką, sociotariniu - $\mathfrak{i}$ bendrą ugdymo kokybę, strateginius švietimo siekius. PKT modelio atskaitos taškas - mokinys, kurio sėkmę ugdymosi procese lemia geresnis pedagogo darbas. Pagrindinis modelio išskirtinumas - pedagogo ir mokyklos PKT poreikių prioritetizavimas ir atsakomybės už poreikių tenkinimą bei PKT proceso įgyvendinimą prisiëmimas. 
Vertinant pedagogui keliamus didelius profesinius iššūkius, aktualus tampa PKT kokybės aspektas. Decentralizuota PKT sistema yra viena stipriųų PKT pusių, tačiau pagrindinis jos trūkumas - kokybės stebėsenos nebuvimas. UPC, vykdant minètą projektą, ŠMM užsakymu 2014 m. sukūrẻ PKT kokybės stebėsenos (vidinès ir išorinès) koncepcijos projektą, kuriuo remiantis PKT kokybės užtikrinimas - tai periodiškai atliekamas PKT kokybės vertinimas ir gerinimas pritaikant kokybės vadybos metodų bei priemonių visumą, siekiant, kad PKT veiklos ir jų rezultatai atitiktų nu(si)statytus PKT kokybès reikalavimus, poreikius bei tikslus (1 pav.).

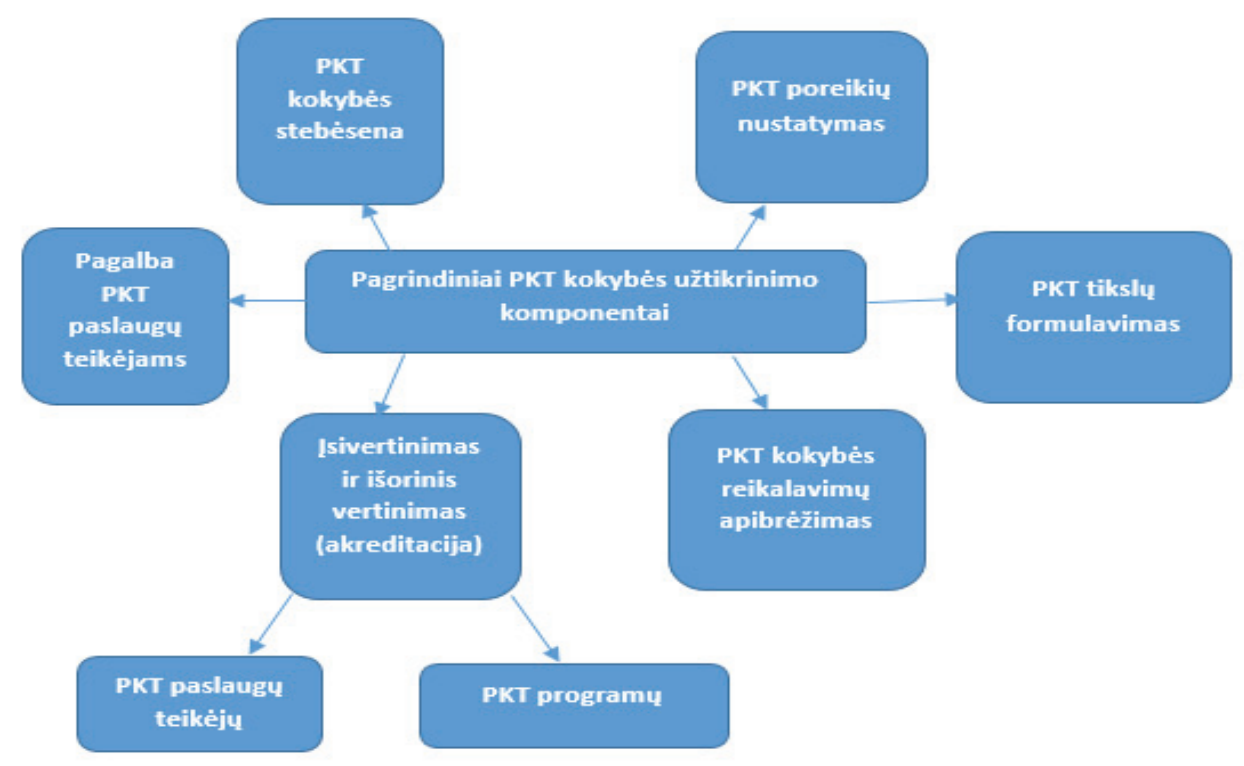

1 pav. Pagrindiniai PKT kokybès užtikrinimo komponentai

ŠMM užsakymu UPC parengtame „PKT kokybès stebėsenos sisteminio modelio koncepcijos pagrindimo projekte“ (2014) pažymima, kad kvalifikacijos tobulinimo paslaugų teikèjai - švietimo centrai ir kitos šias paslaugas teikiančios ịstaigos - atlieka paslaugu planavimo, organizavimo ir teikimo funkcijas: rengia ir vykdo PKT programas bei kitas veiklas, atsižvelgdami ị institucinius ir nacionalinius poreikius bei ŠMM strateginius veiklos planus; vykdo veiklos kokybės ir PKT programų ịsivertinimą; skelbia informaciją apie vykdomas programas, jų akreditavimą, organizuojamus renginius; vykdo teikiamų paslaugų stebėseną. PKT paslaugų teikejjams kokybės stebėsena leidžia ịvertinti paslaugų poreikị, programų pasiūlą ir paklausą, planuoti veiklas, finansinius, materialius ir žmogiškuo- 
sius išteklius, inicijuoti trūkstamų programų rengimą ir teikimą, sudaro galimybes nustatyti silpnąsias veiklos vietas bei pagrindinius veiksmingos veiklos trukdžius ir numatyti, kaip gerinti kokybę.

Pedagogų kvalifikacijos tobulinimo atliktų tyrimų Lietuvoje apžvalga. Lietuvoje 2004 m. vykdant tyrimą „Mokytojų kvalifikacijos tobulinimosi poreikių tenkinimas" nustatyta, kad kvalifikacijos tobulinimo paslaugas teikiančių institucijų atstovai Lietuvos švietimo būklę apibrěžia kaip sparčiai gerèjančią: mokytojų kvalifikacijos sistema decentralizuota, finansavimas siejamas su mokinio krepšeliu, siūloma daug ir ịvairių kvalifikacijos tobulinimo programų, kuriama mokymo programų vertinimo metodika, didejja kvalifikacijos tobulinimo sistemos finansavimas ir renginių interaktyvumas. Iš neigiamų bruožų paminètini: nacionalinès kvalifikacijos tobulinimo strategijos stoka, veiklos tarp skirtingų institucijų nepasidalijimas, menka kvalifikacijos tobulinimo renginių kokybès kontrolè, kartais tik formalus su atestacija siejamas mokytojų interesas dalyvauti kvalifikacijos tobulinimo renginiuose, nesutampantys mokytojų ir mokyklos administracijos interesai, ne visada tikslingai naudojamos kvalifikacijai tobulinti skirtos lěšos (Švietimo būklès tyrimų apžvalga. Valstybinès švietimo strategijos 2003-2012 metams ir Ekonominio bendradarbiavimo ir plètros organizacijos rekomendacijų Lietuvai aspektu, 2008).

UPC minèto projekto I etape atliktas dviejų dalių tyrimas - kiekybinis ir kokybinis, kuris įvertino kvalifikacijos tobulinimo padètị ir apėmè net šešis PKT aspektus.

1. Esamos PKT situacijos apibūdinimas. Kaip vienas veiksnių išskiriamas švietimo centrų sistemos kūrimas. Mokslininkai (Šumskas ir kt., 2011) tyrimo ataskaitoje pateikè du esminius PKT sistemos pokyčius:

- PKT sistemos pokyčiai. Kvalifikacijos tobulinimas turètų būti susietas su praktinès veiklos rezultatais - pokyčiais ugdymo procese. Kaip esminis buvusios sistemos trūkumas nurodomas moksleivio pasiekimų matavimo sistemos nebuvimas, kuris, daugelio ekspertų nuomone, turètų būti tiesiogiai susijęs su kvalifikacijos tobulinimu. Tyrime dalyvavę mokytojai pripažịsta, kad tokia sistema skatintų tobulinti kvalifikaciją ir, esant teigiamam pokyčiui, leistų pajusti profesinị pasitenkinimą, garantuotų teisę reikalauti privilegijų ar paskatinimų didesnio atlyginimo, brangesnių stažuočių, ilgesnių mokamų atostogų savarankiškai tobulinti kvalifikaciją ir kt.

- Tikslingas lèšų PKT skyrimas mokinio krepšelyje. Principas tikslingai skirti lëšas pedagogų tobulinimuisi vertinamas teigiamai. Atskira suma mokinio krepšelyje bendrojo ugdymo mokyklų pedago- 
gams laikoma dideliu palengvinimu organizuojant ir planuojant kvalifikacijos tobulinimą.

2. PKT programų ịvairovès ir kokybès vertinimas. Esamų PKT programų kokybės ir ịvairovès vertinimai yra labai prieštaringi - nuo teigiamų iki visiško atmetimo. Tyrime dalyvavusiems pedagogams, ekspertams lengviausia vertinti praktinę naudą, kuri daugiausia siejama su individualiu konkretaus pedagogo gebejjimu atrasti, pritaikyti ir perduoti programose igytas žinias. Formaliai pripažįstama, kad programų yra gausu ir teoriškai mokytojas turi galimybę rinktis. Kita vertus, dažnai kursų turinys kartojasi, net jei laikui bėgant keičiami jų pavadinimai, naudojamos tos pačios formos ir patys mokymai yra labiau formalaus pobūdžio. Besikartojantis turinys ir formos netiesiogiai formuoja ,persisotinimo“ jausmą, kuris kuria „visko žinojimo“ iliuziją ir mažina norą toliau tobulintis, skatina inertiškumą ir žemą savirefleksiją ar kritiškumą. Aptariant PKT programų kokybę, daugelis ekspertų teigè, kad ịvertinti jų kokybę yra nerealus uždavinys. Kalbant apie galimus programų turinio kūrejus, visi respondentai nurodè, kad Lietuvos mokytojai galètų kurti konkurencingas ir vertingas programas, jei tam būtų sudarytos sąlygos. Respondentų nuomone, mokytojų dalyvavimas kuriant programas skatintų jų tarpusavio konkurenciją ir slopintų norą dalintis patirtimi, šio darbo atskirai neapmokejjus.

3. PKT programų formų ịvairovès ir efektyvumo vertinimas. Šiuo metu populiariausios PKT formos - kursai, seminarai, stažuotès ir stebejjimai. Jaunesnès kartos pedagogai ir dalis ekspertų nurodo, kad populiarejja ir tobulinimasis nuotoliniu būdu, nors ši forma nelaikoma lygiaverte tradicinèms. Kaip dažniausiai siūlomos PKT formos minimi kursai ir seminarai, nors, manoma, kad jie mažai efektyvūs. Stažuotès vertinamos kaip veiksmingos, derinančios praktinių ir teorinių žinių tobulinimą stebint ir aktyviai dalyvaujant. Manoma, kad efektyviausiai stažuotès galètų vykti Lietuvoje. Savišvieta, kaip PKT forma, nelaikoma prasminga, nesukūrus pasiektų rezultatų vertinimo sistemos. Ekspertų nuomone, savišvieta gali būti veiksminga tik tuo atveju, jei yra nustatyti jos tikslai ir laikas, per kuri jie turi būti pasiekti. Tyrimo autorių (Šumskas ir kt., 2011) teigimu, stebẻjimas, kaip viena iš PKT formų, laikomas patraukliu dèl kelių dalykų (2 pav.): 


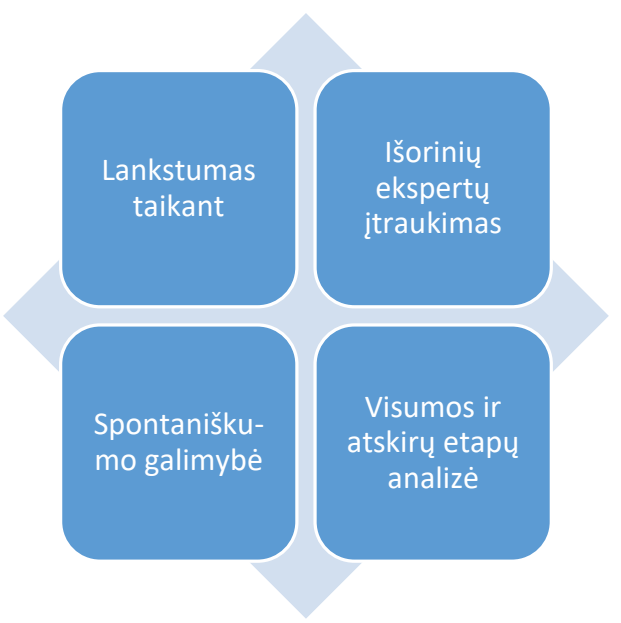

2 pav. Stebèjimo, kaip PKT formos, taikymo privalumai, remiantis UPC projekto „PKT ir perkvalifikavimo sistemos plètra“ tyrimo duomenimis (2011)

Šiuo metu galètų būti skiriami du igytos kvalifikacijos efektyvumo pripažinimo lygmenys - formalusis ir neformalusis. Formaliuoju lygmeniu pripažistamas ne pats kvalifikacijos tobulinimas (pokytis), kuris nematuojamas, o igytas formalus dokumentas - sertifikatas. Neformaliuoju lygmeniu - kolegų pripažinimas stebint darbo procesą ir jo rezultatus (vertinant moksleivių ir tèvų atsiliepimus, įdiegtas inovacijas, popamokinès veiklos rezultatus ir aktyvumą), tačiau šiuo atveju sunkiai skiriama, kiek esamam rezultatui turejo įtakos kvalifikacijos tobulinimas. Kaip vienas veiksnių, netiesiogiai nurodančių i sẻkmingą individualų kvalifikacijos tobulinimo procesą, yra pedagogo dalyvavimas tame procese lektoriaus ar programy kūrejjo vaidmenyse. Nors dauguma pedagogų pripažįsta, kad turi galimybę dalyvauti ịvairaus pobūdžio programose, praktiškai panaudoti ịgytas žinias tiesioginiame darbe sunkiau dèl to, kad pačios programos neretai yra trumpalaikès, o grižtamojo ryšio palaikymo galimybė yra labiau deklaratyvi. Nors, grįžę iš ịvairių PKT renginių, mokytojai pristato savo patirtị (išgirstą informaciją, gautą medžiagą) metodinèse grupèse, daugelis pripažino, kad tokių pristatymų vertẻ kitų tobulejjimui yra abejotina. Pristatymai yra labiau informacinio pobūdžio, leidžiantys susidaryti nuomonę apie programą, lektorius ir nuspręsti, ar verta joje dalyvauti.

4. PKT procesų persikèlimo ị mokyklas vertinimas. Kaip šiuo metu populiari, bet vis dar nauja forma nurodomi mokymai konkrečioje mokykloje. Mokytojų ir administracijos atstovų ypač vertinami ilgalaikiai mokymai, trunkantys savaitę ar dvi. Pedagogai skiria dvi naudas: daugiau laiko ir 
dėmesio gali skirti mokymo turiniui, per daug neatitrūkdami nuo mokymo proceso; mokymuose dalyvauja daugiau kolegų, tai ịgalina sklandžiau ịgyvendinti naujoves praktikoje.

5. PKT poreikio nustatymas konkrečioje mokykloje. Vienas esminių esamos PKT sistemos trūkumų - praktiškai nevykstantis individualių ir kolektyvinių PKT poreikių nustatymas. Nors dauguma pedagogų gali teigti, kad yra pildę ịvairias poreikių nustatymo anketas, nè vienas negali nurodyti, kaip tų anketų rezultatai buvo panaudoti. Poreikio nustatymo mechanizmas turètų būti neatsiejamas nuo kvalifikacijos pokyčio matavimo mechanizmo, kitaip būtų sunku kalbèti apie PKT procesų tęstinumą ir ilgalaikius tikslus, atsižvelgiant $\mathfrak{i}$ visos mokyklos bendruomenès poreikius. Mechanizmas, matuojantis mokytojo darbo rezultatą, juo laikant moksleivio pasiekimų pokytị, turi būti sukurtas ir įdiegtas kaip PKT sistemos dalis. Dauguma ekspertu pabrèžia, kad labai svarbu matuoti, o ne vertinti pokyti ar kaip nors kitaip reitinguoti mokytojus. PKT procesas turi būti tęstinis, apimantis ne tik aktyvius mokymus, bet ir tam tikrą praktinio taikymo stebėseną, konsultacijas, įtraukiant ir programų teikejjus / lektorius. PKT procesai galètų būti veiksmingi tik nuosekliai igyvendinus visus etapus (3 pav.).

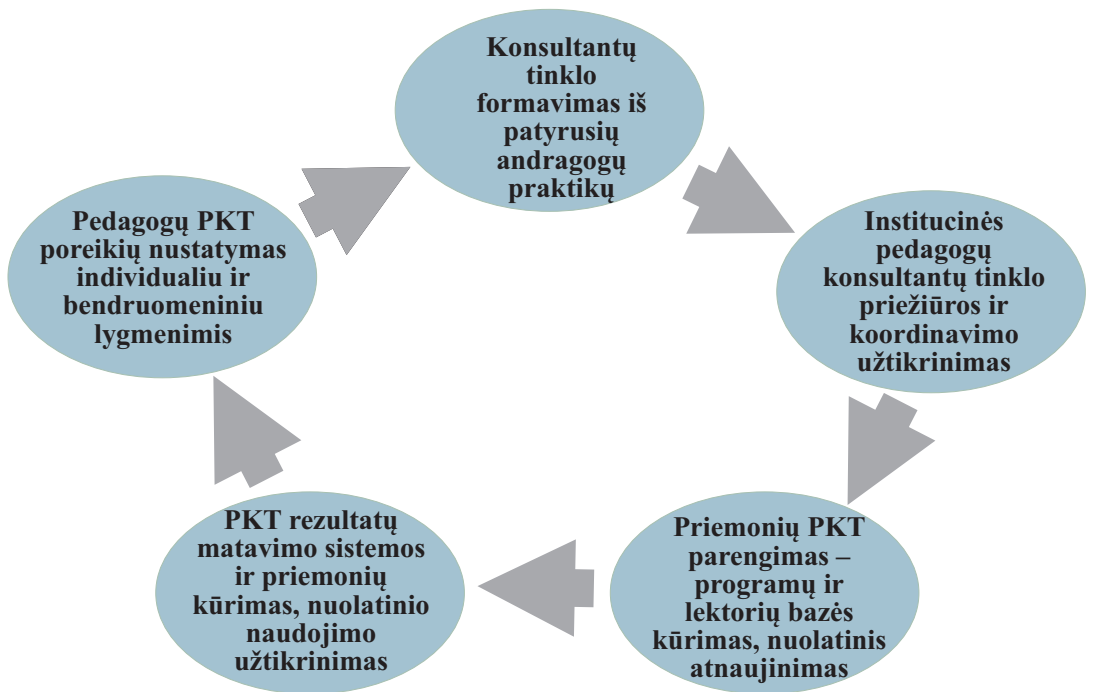

3 pav. PKT procesų veiksmingumo užtikrinimas, remiantis UPC projekto „PKT ir perkvalifikavimo sistemos plètra“ tyrimo duomenimis (2011)

6. Požiūis ị PKT teikèjų apskaitą, sertifikavimą. Kadangi PKT ilgą laiką buvo susietas su atestacijos procesais, vienu reikšmingiausių programos pasirinkimo kriterijų pedagogams ir mokyklų administracijai buvo, ar teikèjas / 
lektorius yra atestuotas, t. y. ar gali dalyviui išduoti dalyvavimą patvirtinantị sertifikatą. Didžioji dalis ekspertų mano, kad šiuo metu PKT programos ir jas perteikiantys lektoriai turi būti atrenkami ir sertifikuojami dèl didelès nesąžiningų ar švietimo politikos tikslų neatitinkančių produktų pasiūlos.

Apibendrinant galima teigti, kad Lietuvos PKT sistemoje vyksta teigiami pokyčiai: vyrauja PKT paslaugų teikẻjų ir formų ịvairové, aiški finansavimo tvarka, sukurta teisès aktų bazė, užtikrinanti ne tik tęstinị kvalifikacijos tobulinimą, bet ir praplečianti esamas veiklos sritis; atliekami PKT tyrimai, kurių rezultatais remiantis kuriami ịvairūs PKT kokybę užtikrinantys modeliai. Tačiau nacionaliniu mastu kalbant apie PKT renginiams būdingą fragmentiškumą ir trumpalaikiškumą, panašu, kad valstybiniam PKT sistemos modeliavimui taip pat būdingas fragmentiškumas: 2011 metais atliktų tyrimų pagrindu sukurti PKT (2012) ir PKT stebėsenos (2014) modeliai iki šiol teisiškai nepatvirtinti. PKT paslaugų kokybė priklauso nuo savivaldybėse veikiančių pedagogų švietimo centrų darbuotojų profesionalumo.

Andragogo profesinès veiklos pripažinimas Lietuvoje ir teisinis reglamentavimas. Andragogo profesinès veiklos teisinis reglamentavimas gerokai atsilieka nuo mokslininkų pagrịsto šios profesijos vaidmens. Galimai tam ịtakos turi įvairialypiai andragogo vaidmenys, kuriuos skirtingose profesinèse situacijose atlieka kitų profesijų atstovai, disponuojantys andragogui būtinomis kompetencijomis. Dar 2008 m. A. M. Juozaitis pripažino Lietuvoje vyravusią nuostatą, kad bet kuris laisvalaikiu gali būti andragogu. 2008 m. mėginta skaičiuoti organizacijas, sutelkusias andragogo profesijai artimus specialistus. Tuo metu Lietuvoje buvo 368 kryptingai suaugusiujų švietimu užsiimančios organizacijos ir apie 400 ịvairaus pobūdžio konsultacinių įmonių (Juozaitis, 2008). Duomenų, kiek tiksliai 2013 m. Lietuvoje buvo praktikuojančių andragogų, nèra (Jatkauskienè, 2013). LR Vyriausybès kanceliarijos mokymosi visą gyvenimą (toliau - MVG) tyrimo ataskaitoje (2015) teigiama, kad, be andragogo profesijos naujumo, sunkumų skaičiuojant profesionalius andragogus kyla ir dẻl kitų priežasčių: 1) andragogų statusas vis dar išlieka labai neapibrěžtas, dalis jų save priskiria kitos turimos profesijos arba žmogiškujų išteklių tarnybų atstovams; 2) andragogai atlieka ịvairias - skirtingas veiklos funkcijas, atsižvelgiant ị tai, kokioje institucijoje ar sektoriuje dirba; 3) andragogų darbo statusas labai ịvairus: jie gali dirbti visu etatu ir keletą metu toje pačioje institucijoje, atlikdami daugelị funkcijų ir vaidmenų, o kartais jų veikla yra tik fragmentiné, laikina ar papildoma; 4) andragogo profesiją vertinant mažiau formaliai, jai galima priskirti ir kitų profesijų atstovus, kartais dirbančius suaugusiujų švietimo sistemoje: pedagogus, švietimo vadybininkus, administratorius, nevyriausybinių organizacijų atstovus, mokymų vadovus ir kt. (Jatkauskiené, 2013). Galima tik spèlioti, ar ateityje situacija reikšmingai keisis. Tai gali lemti keli veiksniai (6 lentelè). 
6 lentele. Veiksniai, galintys lemti andragogo profesijos teisinị pripažinimą

\begin{tabular}{|c|c|}
\hline Veiksniai & Pagrindžiantys įrodymai \\
\hline $\begin{array}{l}\text { Priimti ir } \\
\text { koreguoti } \\
\text { aktualūs teisès } \\
\text { aktai }\end{array}$ & 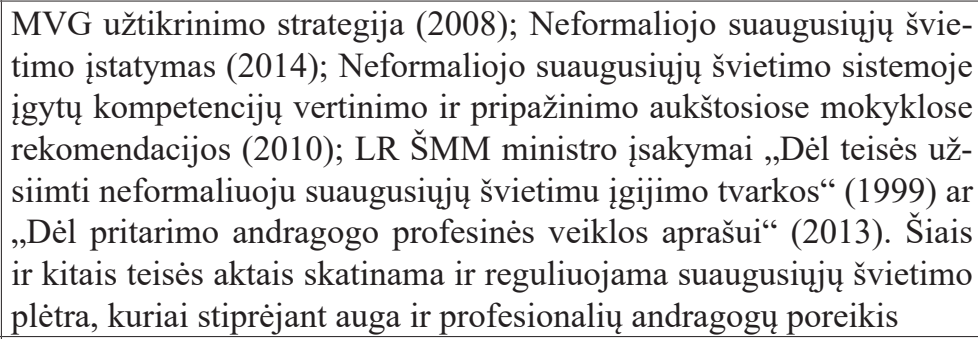 \\
\hline $\begin{array}{l}\text { ES struktūrinès } \\
\text { paramos } \\
\text { tikslingas } \\
\text { naudojimas } \\
\text { MVG }\end{array}$ & $\begin{array}{l}\text { MVG prioritetui svarbus projektas „Suaugusiujų švietimo sistemos } \\
\text { plètra suteikiant besimokantiems asmenims bendrąsias kompetenci- } \\
\text { jas“ (2012-2015), kurio veiklos apėmė andragogams skirtus moky- } \\
\text { mus ir teorinės andragoginės literatūros knygų serijos išleidimą. Tai } \\
\text { padeda andragogams tiek metodiškai, tiek siekiant ịtvirtinti savo pro- } \\
\text { fesiją kaip aktualią, atkreipti i ją visuomenès dėmesi }\end{array}$ \\
\hline $\begin{array}{l}\text { Andragogo } \\
\text { profesijos } \\
\text { ịtraukimas ị } \\
\text { formalią švietimo } \\
\text { sistemą }\end{array}$ & $\begin{array}{l}\text { Andragogikos bakalauro ir magistro studijų programos vykdomos } \\
\text { Klaipėdos universitete. Vytauto Didžiojo universitetas siūlo nuotolinę } \\
\text { Švietimo ir informacinių technologijų programą, suteikiančią andra- } \\
\text { gogikos bakalauro laipsnị. Kiti universitetai (Šiaulių, Mykolo Rome- } \\
\text { rio, Sveikatos mokslų, Lietuvos edukologijos) andragogiką ịtraukia ị } \\
\text { studijų programas kaip privalomą magistro studijų dalị ar pasirenka- } \\
\text { mą bakalauro studijų dalyką }\end{array}$ \\
\hline
\end{tabular}

LR Vyriausybès kanceliarijos MVG tyrimo ataskaitoje (2015) andragogai priskiriami suaugusiujų švietėjams ir laikomi viena labiausiai institucionalizuotų suaugusiųjų švietejjų grupių. Tačiau pripažistama, kad jie susiduria su įvairiais šios specialybės asmenų rengimo iššūkiais. Kita suaugusiųų švietėjų grupe laikomi MVG paslaugas teikiantys juridiniai ir fiziniai asmenys, $i \mathrm{z}$ ją patenka įvairius vaidmenis atliekantys andragogai: mokymus suaugusiesiems vedantys lektoriai, mokymų vadovai, organizatoriai, akcijų iniciatoriai ir pan. Ataskaitos autorių teigimu, daugiau MVG paslaugų teikèjų susitelkę didžiuosiuose Lietuvos miestuose, tuo tarpu regionuose jų stinga. MVG paslaugų teikėjams konkuruojant, didžiuosiuose miestuose kyla šių paslaugų kokybė ir priešingai - ten, kur teikèjų mažai, - prastesnè ir teikiamų MVG paslaugų kokybè. Taigi akivaizdu, kad pastarujų metų teoriniai svarstymai apie andragogo veiklą paskatino dèmesi andragogo profesijai, imta rūpintis jos įteisinimu, šios profesijos kvalifikacijos sukūrimu. Svarbu yra tai, kad ši domejjimąsi skatina ir palaiko politinès iniciatyvos tiek Europoje, tiek ir Lietuvoje.

LR Neformaliojo suaugusiųų švietimo ir tęstinio mokymosi įstatymu (2014) apibrèžiamas teikèjas, kuriam suteikiama teisè vykdyti mokymosi programas ir tobulinti valstybès tarnautojų, kitų biudžetinių įstaigų darbuotojų kvalifikaciją. 
Nors įstatymas nenumato, kad minètas paslaugų teikejo funkcijas gali atlikti tik andragogas, akivaizdu, kad jo reglamentuojamas neformaliojo suaugusiųjų švietimo ir tęstinio mokymosi organizavimas yra labai artimas išskirtoms andragogo atliekamoms veikloms: 1) planavimas ir įgyvendinimas; 2) dalyvių informavimas ir konsultavimas; 3) kokybès užtikrinimas; 4) įgyvendinimo stebėsena ir vertinimas; 5) asmenų ịgytų kompetencijų pripažinimas.

Šiek tiek liūdina faktas, kad andragogo profesijos vis dar nèra Lietuvos profesijų klasifikatoriuje (2012), tačiau daugiau pozityvumo šiuo atveju suteikia $2013 \mathrm{~m}$. spalio 22 d. švietimo ir mokslo ministro patvirtintas Andragogo profesinès veiklos aprašas, skatinantis plèsti MVG paslaugas, gerinti jų kokybę, didinti besimokančiųų visą gyvenimą skaičių. Aprašu galima remtis kuriant andragogų rengimo ir kvalifikacijos tobulinimo programas, sudarant andragogo darbo vietos instrukcijas, pareigybių aprašus, viešųų pirkimų konkursų reikalavimus. Besimokantiems suaugusiesiems jis turètų užtikrinti aukštesnę teikiamų paslaugų kokybę.

Nèra abejonès, kad Aprašui patvirtinti ir LR Neformaliojo suaugusiųų švietimo ir tęstinio mokymosi įstatymui (2014) atnaujinti įtakos turèjo LR Seimo $2012 \mathrm{~m}$. patvirtinta Valstybės pažangos strategija „Lietuva 2030“, kuri nubrěžè valstybès viziją ir raidos prioritetus bei jų igyvendinimo kryptis iki 2030 metų. Šios strategijos vienas svarbiausių siekinių - sukurti veiksmingą MVG sistemą, pritaikančią informacinių ryšių, technologijų galimybes, užtikrinančią dinamiškai visuomenei būtinų žinių bei gebejjimų ịgijimą ir tobulinimą. Ṣ̌ tikslą atitinka kiti pagrindiniai Lietuvos strateginiai dokumentai, pvz., MVG skatinimas, kaip vienas prioritetų, yra numatytas 2014-2020 m. Nacionalinèje pažangos programoje. Joje pažymima, kad bus siekiama gerinti švietimo kokybę, prieinamumą ir paslaugų įvairovę, atskirą dėmesị skiriant suaugusiujų mokymosi sąlygoms bei paskatoms. Be to, ìvardijamas veiksmingos pagalbos vertinant savo galimybes ir norus, renkantis ir valdant karjerą (mokymosi ir profesinį kelią) bei tobulinantis, užtikrinimas.

Taigi MVG skatinimas valstybès strateginiuose dokumentuose, be abejonès, ịtvirtina ir andragogo vaidmenị. Nors dalis tyrejų teigia, kad ateityje mokymosi procesą puikiai palaikys mokytojai robotai ar išmaniosios mokymosi programos (Meltzoff ir kt., 2005), suaugusiujų švietejjas, andragogas vis dar užima svarbią vietą motyvuojant besimokančiuosius. Irodyta, kad žmonės geriau mokosi stebimi tų, kuriems svarbūs jų rezultatai. Taigi suaugusiesiems svarbus žmogiškasis ryšys su švietejju - andragogu, karjeros konsultantu ar kitu MVG paslaugas teikiančiu asmeniu. Ateityje vis labiau gali būti pereinama nuo švietejo, kaip informacijos ir žinių perdavejo bei vertintojo, iki švietėjo ịkvèpèjo, mentoriaus ir patarejjo. Ateityje, tikètina, švietėjas (MOSTA, 2013): padès kuruoti mokymosi procesą ir jame tarpininkauti, bet jo nebevaldys; diferencijuos ir personalizuos mokymąsi pagal kiekvieno gebejjimus, vertybes bei polinkius; išmanys ir kompleksiškai taikys ịvai- 
rias mokymosi formas bei metodus; automatizavus pažangos vertinimą, prižiūrès sistemą, analizuos kiekvieno besimokančiojo pažangą; ne tik taikys, bet ir kurs bei keis mokymosi turini pagal kiekvieno asmens poreikius.

Apibendrinant galima teigti, kad, nepaisant andragogo profesijos pripažinimo kelyje pasitaikančių sunkumų, Lietuvos strateginiuose dokumentuose numatytos veiklos kryptys artimiausiais metais turès užtikrinti andragogo vietą ir vaidmeni suaugusiujų švietimo sistemoje. Žvelgiant iš globalios visuomenès perspektyvos ir atsižvelgiant ị andragogo profesinès veiklos sričių, funkcijų, būtinų kompetencijų gausą ir atliekamų vaidmenų įvairialypiškumą, andragogas organizatorius neišvengiamai bus vienas iš suaugusiujų švietimo dalyvių, kurio profesionali pagalba bus būtina, siekiant užtikrinti kokybiškas PKT paslaugas.

\section{Išvados}

Atliktos teorinès analizės pagrindu galima daryti išvadą, kad pedagogų kvalifikacijos tobulinimas yra sudettingas profesionalizacijos procesas, prasidedantis turimos kvalifikacijos įsivertinimu ir besibaigiantis igytų kompetencijų praktiniu pritaikymu, jų naudos mokinio mokymosi rezultatams matavimu. Mokytojas, planuodamas kvalifikacijos tobulinimą, turi atsižvelgti ne tik ị savo profesinès veiklos asmeninị vertinimą, bet ir vadovautis organizacijos kolektyviniais kvalifikacijos tobulinimo tikslais bei projektuoti naujų igytų kompetencijų perkèlimą ị profesinę veiklą konstruojant jas ant turimos kvalifikacijos pagrindo. Šiam, skirtingai nei mokinių, nelinijiniam suaugusiųjų mokymosi modeliui būtinas profesionalumas, pasirenkant produktyviausią kompetencijų ịgijimo būdą, tad šiame procese pedagogui dažnai reikia profesionalios pagalbos.

Mokslinių šaltinių analizė atskleidė andragogo organizatoriaus atliekamų vaidmenų, funkcijų, profesinès veiklos sričių ir tipinių situacijų ịvairialypiškumą, sudètingumą. Andragogo, organizuojančio pedagogu kvalifikacijos tobulinimą, veiklos spektras labai platus. Nuo andragogo organizatoriaus profesionalumo priklauso pedagogų kvalifikacijos tobulinimo paslaugų kokybė. Andragogui organizatoriui keliami aukšti reikalavimai pabrèžia tiek vidaus, tiek išorès profesionalizacijos reikšmę.

LR teisès aktų, reglamentuojančių pedagogų kvalifikacijos tobulinimo ir andragogo profesinę veiklą, analizè atskleide esminius pedagogo ir andragogo profesijų pripažinimo skirtumus. Seniai pripažintos pedagogo profesijos kvalifikacijos tobulinimo srityje vyrauja teigiamos tendencijos: sukurta teisès aktų bazè, reglamentuojanti aiškią finansavimo tvarką, paslaugų teikejjų ir formų ịvairovę; atliekami ìvairūs moksliniai tyrimai, kuriais remiantis vèliau papildomi esami ir sukuriami nauji teisès aktai. Andragogo profesija, nors jo veiklos teisinis reglamentavi- 
mas pamažu skinasi kelią, dar vis patiria pripažinimo sunkumų ir reikalauja daug mokslininkų pastangų, kad išorès profesionalizacijos procese būtų išgrynintas andragogo statusas, jo atliekami vaidmenys, funkcijos ir kt. Tikimasi, kad Lietuvos strateginiai dokumentai, atsiradę ES strateginių dokumentų pagrindu, padès užtikrinti andragogo vaidmenị tiek pedagogų kvalifikacijos tobulinimo, tiek kitose suaugusiųų švietimo srityse.

\section{Literatūra}

Andragogo profesinès veiklos aprašas. (2013). [Interaktyvus]. Prieiga internete: <http://www.smm.lt/web/lt/ teisesaktai/tei/ministro-isakymai> [žiūrèta 2018-04-10].

Andriekienè, R. M., Martišauskienė, D. (2013). Švietimo darbuotojų požiūris ị paslaugų kokybės valdymą andragoginès veiklos aspektu. Andragogika, Nr. 1 (4), p. 139-155. Klaipėda: KU leidykla.

Andriekienė, R. M. (2011). Andragogų profesionalizacija atliekamų vaidmenų aspektu. Andragogika, Nr. 2, p. 13-29. Klaipèda: KU leidykla.

Barkauskaitė, M. (2006). Suaugusiuju pedagogikos gairès. Vilnius: VPU leidykla.

Buiskool, B. J., Broek, S. D., Lakerveld, J. A., Zarifis, G. K., Osborne, M. (2010). Key competences for adult learning professionals. Thousand Oaks, CA: Sage.

Jatkauskienė, B. (2013). Andragogu profesionalizacijos sistemos profesionali raiška. Monografija. Klaipėda: KU leidykla.

Jatkauskienė, B., Jatkauskas, E. (2010). Andragogų profesionalizacija veiklos daugiafunkcionalumo aspektu. Mokytojų ugdymas, Nr. 14, p. 23-39. Šiauliai: ŠU leidykla.

Juozaitis, A. M. (2008). Suaugusiujų mokytojų profesionalizacija tobulinant andragoginę veiklą. Monografija. Kaunas: VDU leidykla.

Le Boterf, G. (2010). Dar karta apie kompetenciją. 15 pasiūlymu iprastoms idèjoms išplètoti. Klaipèda: KU leidykla.

Lietuvos mokslo būklès apžvalga. (2013). [Interaktyvus]. Prieiga internete: <http://www.mosta.lt/lt/images/ documents/stebesena/bukles_apzvalga/Mokslo_b\%C5\%ABk1\%C4\%97s_ap $\%$ C5\%BEvalga.pdf> [žiūrèta 2018-03-22].

Lietuvos profesiju klasifikatorius. (2012). [Interaktyvus]. Prieiga internete: <http://www.profesijuklasifikatorius. lt/?q=lt/node/13440> [žiūrèta 2018-04-15].

LR Neformaliojo suaugusiujų švietimo ir tęstinio mokymosi įstatymas. (2014). [Interaktyvus]. Prieiga internete: $<\mathrm{http}: / /$ www3.lrs.lt/pls/inter3/dokpaieska.showdoc_1?p_id=478674> [žiūrèta 2018-04-03].

LR Seimo nutarimas Nr. XI-2015 „,Dél valstybès pažangos strategijos „,Lietuvos pažangos strategija „,Lietuva 2030" patvirtinimo". (2012). [Interaktyvus]. Prieiga internete: < https://e-seimas.1rs.lt/portal/legalAct/lt/ TAD/TAIS.425517> [žiūrèta 2018-03-26].

LR Seimo nutarimas Nr. 1482 „Dèl 2014-2020 metu Nacionalinès pažangos programos patvirtinimo “. (2012). [Interaktyvus]. Prieiga internete: <https://e-seimas.lrs.lt/portal/legalAct/lt/TAD/TAIS.439028> [žiūrèta 2018-03-22].

Lietuvos Respublikos švietimo įstatymas. (2011). [Interaktyvus]. Prieiga internete: $<\mathrm{http}: / / \mathrm{www} 3.1 \mathrm{rs} .1 \mathrm{t} / \mathrm{pls} / \mathrm{inter} 2 /$ dokpaieska.showdoc_1?p_id=458774> [žiūrèta 2018-04-02].

LR Švietimo ir mokslo ministro įsakymas Nr. V-2319 „Dèl neformaliojo suaugusiujų švietimo sistemoje igytu kompetencijų vertinimo ir pripažinimo aukštosiose mokyklose rekomendacijų patvirtinimo “. (2010). [Interaktyvus]. Prieiga internete: <https://e-seimas.1rs.lt/portal/legalAct/lt/TAD/TAIS.389755> [žiūrèta 2018-03-02].

LR švietimo ir mokslo ministro ịsakymas Nr. V-774 „Dèl reikalavimu mokytoju kvalifikacijai aprašo patvirtinimo“. (2014). [Interaktyvus]. Prieiga internete: <https:/www.e-tar.lt/portal/lt/legalAct/85dc8a70 5b4d11e487eff7b424bd0f08> [žiūrèta 2018-03-02].

Meltzoff, A. N., Kuhl, P. K., Movellan, J., Sejnowski, T. J. (2005). Foundations for a New Science of Learning. Science, No. 325. Prieiga internete: <https://www.ncbi.nlm.nih.gov/pmc/articles/PMC2776823/> [žiūrèta 2018-03-26]. 
Mokymosi visa gyvenima užtikrinimo strategija. (2008). [Interaktyvus]. Prieiga internete: $<$ https://www.e-tar.lt/ acc/legalAct.html?documentId=TAR.BCAEABD601EC> [žiūrèta 2018-04-02].

Pedagogu kvalifikacijos tobulinimo kokybès stebèsenos sisteminio modelio koncepcijos pagrindimas. (2014). [Interaktyvus]. Prieiga internete: <http://www.upc.smm.lt/projektai/pkt/rezultatai/stebesena/Pedagogukvalifikacijos-tobulinimo-kokybes-stebesenos-sisteminio-modelio-koncepcijos-pagrindimo-projektas. pdf $>$ [žiūrèta 2018-04-02].

Pedagogu kvalifikacijos tobulinimo koncepcija. (2012). [Interaktyvus]. Prieiga internete: <http://www.upc.smm. 1t/naujienos/pkt/koncepcija.php> [žiūrèta 2018-04-10].

Pedagogu kvalifikacijos tobulinimo modelis. (2012). [Interaktyvus]. Prieiga internete: <http://www.upc.smm.lt/ projektai/pkt/naujienos/modelis/PKT_modelis.pdf> [žiūrèta 2018-04-02].

Pedagogu kvalifikacijos tobulinimo sistemos analize. (2011). [Interaktyvus]. Prieiga internete: $<$ http://www.upc. smm.lt/projektai/perkva/naujienos/PKT_analize_120105.pdf> [žiūrèta 2018-04-02].

Pollard, A. (2002). Refleksyvusis mokymas. Veiksminga ir duomenimis paremta profesine praktika. Vilnius: Garnelis.

Siebert, H. (2007). Teorijos ir praktikos squveika. Vilnius: Kronta.

Švietimo raidos Lietuvoje ịžvalgos. Medžiaga diskusijoms. (2013). Vilnius: ŠCA leidykla.

Švietimo būklès tyrimu apžvalga Valstybinès švietimo strategijos 2003-2012 metams ir Ekonominio bendradarbiavimo ir plètros organizacijos rekomendaciju Lietuvai aspektu. (2008). Vilnius: ŠCA leidykla.

Tarptautinių žodžių žodynas. (2008). Vilnius: Alma littera.

Teresevičienė, M., Gedvilienè, G., Zuzevičiūtė, V. (2006). Andragogika. Kaunas: VDU leidykla.

Valstybine švietimo 2013-2022 metu strategija. (2013). [Interaktyvi]. Prieiga internete: <https://www.etar.lt/ portal/legalAct.html?documentId=b1 fb6cc089d911e397b5c02d3197f382> [žiūrèta 2018-04-15].

Villegas-Reimers, E. (2003). Teacher Professional Development: an international review of the literature. Paris: UNESCO International Institute for Educational Planning (IIEP).

Zuzevičiūtė, V., Teresevičienè, M. (2008). Suaugusiuju mokymasis. Andragoginès veiklos perspektyva ir andragoginès veiklos modelis. Kaunas: VDU leidykla.

\section{THE ROLE OF ANDRAGOGUE-ORGANIZER IN TEACHERS' IN-SERVICE PROFESSIONAL DEVELOPMENT}

\section{Nomeda Skliuderienė, Gitana Tolutienė}

Summary

On the basis of qualification development events' statistics from recent years in Lithuania it appears that when the number of events for school communities and teams increases the communities understand the importance of the ability to act together. Team learning is one of the features of a learning organisation. In the context of teachers' qualification development model built in Lithuania and existing in other countries, when teachers' qualification development has to reflect it's own priorities and activity directions as well as the priorities and activity directions of the educational institution coherence of individual and collective competences can be treated not only as a condition of successful communication and cooperation but as one of the organisation's objectives. B. Jatkauskienè (2013) cites Corn, according to whom teachers' competence is collective. Competence is expected of the teachers' (of the whole school's, of the whole institutions') staff. Competence should not be expected from the teacher in the beginning of his carrier; The teacher 
will have to learn during his whole professional carrier and stay hungry for new knowledge and intellectual curiosity. If he will not have it himself, he will be unable to transmit it to his students. As regards teachers' qualification development it is emphasized that qualification development consistently continues the teachers' training that started in higher educational institution and has to last the whole period of his professional activity. Requirements raised for teachers stress that the teacher has to have good knowledge of his subject as well as certain personal qualities. Thus, his activity sphere and responsibility is expanded, from transferring the subjects' programme to the student to individual approach and action in separate professional situations. Documents regulating teachers' qualification development (LR Education Act 2011; Government Education Strategy's 2013 provisions of 2013-2022; The Conception of Teachers' Qualification Development 2012; Description of Requirements for Teachers' Qualification 2014 and other) provides the teacher an opportunity to improve personal, as well as educational institution's or national needs of qualification development. In organising the teachers' qualification development process the main role is played by the andragoguge organiser and his professionalism in mastering educational, management and research activity spheres.

R. M. Andriekienè (2011) claiming that andragoguge organiser's main activity in the sphere of adult education is divided into internal (consultation of his own organisation) and external (consultation of clients who ordered courses) highlights that more requirements for him is raised although it remains not clear how and what management roles performed by him has the biggest influence in practical activity in cooperation of all operators of the adult education process: learners, andragoguge organiser, lecturer, organisation's administration and other. Andragoguge organiser's activity is too complicated for similar provisions and instructions to be applied for all adult education institutions. Development of learning environments, increasing number of it's types makes andragoguge organiser's activity especially dependant from an adult education strategy prevailing in a particular institution, therefore regulation of this activity is the decision of adult educational institution. As regards teachers' qualification development, it is very important to justify the significance of an andragogue who has all the characteristics of a professional. It has an enormous importance in the context of recognition of the andragogue's profession. Teaching profession has long been recognised, according to Goode, in 1960. It corresponds with the main characteristics of the profession: teachers have a bureaucratic legitimized status, a common professional identity and values, functions and roles that they perform. Meanwhile, although efforts to socially and legally recognise andragogue's professional activity are observed, it is neglected and denied in reality (Andriekiené, 2011). Although on the 22nd of 
October, 2013 description of andragogue's professional activity that defines it's purpose, objectives, tasks and competences was approved by the Minister of Education and Science the andragogue's profession is not yet included in the Lithuanian Classification of Occupations. Consequently, in the absence of andragogue's post, it is possible to report only professional roles that he performs, including the role of andragogue organiser.

The analysis of scientific literature, acts of Lithuanian laws and teacher training studies in Lithuania showed that teachers' professional development is a complex process consisting of professional activity assessment, planning, development (learning), practical application, reflection, and quality assurance with respect to cycle repeated quality improvement.

Scientific problem: what is the role of the professional organizer andragogue to teacher development efficiency?

Research object: andragogue organizer role for teacher developmentin.

Research aim: to analyze theoretically andragogue organizer role in the field of teacher development.

Research goals:

1) to analyze the concept of teacher development;

2) to reveal andragogue organizer and other roles and functions in the field of teacher development;

3) to analyze the Ministry's legislation on teacher development and andragogue professional activity.

Research methods:

Theoretical: the descriptive analysis of science sources and documents accomplished in order to reveal the importance of teachers' continuing training and professionalizm of andragogue organizer and to highlight the importance of teacher training and andragogue organizer activity positive sides and problems connections.

Novelty and significance of the article:

The article isbased on the concept of teacher development. The andragogue activity versatility and multi-functionality is disclosed and the value of andragogue organizer professionalism to teacher development efficiency is proved.

Conclusions:

On the basis of conducted theoretical analysis it can be concluded that teachers' qualification development is a complicated professionalization process beginning with self-assessment of the possessed qualification and ending with practical application of acquired competences and assessment of it's benefit to students' learning results. When planning his qualification development the teacher has to take into account not only his personal professional activity assessment but follow 
common collective qualification development objectives of the organisation and design integration of newly acquired competences into his professional activity while constructing them on the basis of the possessed qualification. This non-linear adult education model, unlike students' education model, requires professionalism in choosing the most productive way to acquire competences. Therefore, in this process the teacher needs andragogue's professional assistance.

Scientific source analysis revealed diversity and complexity of andragogue organiser's performed roles, functions, spheres of professional activity and typical operational situations. The range of activity of the andragogue organising teachers' qualification development is very broad. Quality of teachers' qualification development services depends on the andragogue organiser's professionalism. High requirements raised for the andragogue organiser emphasises internal and external importance of his professionalization.

Analysis of LR legal acts regulating teachers' qualification development and andragogue's professional activity has shown the fundamental differences of recognition of teachers' and andragogues' professions. Positive trends prevail in the sphere of long recognised teaching profession's qualification development: created legislation data base that regulates clear financing arrangements, diversity of service providers and forms; various scientific research conducted on the basis of which existing legal acts are supplemented and new legal acts are created later. In the meanwhile, even though legal framework for andragogue's activity is slowly taking hold his profession encounters recognition difficulties and requires special effort of researchers so that the andragogue's status, performed roles, functions, etc. would be specified in the external profesionalization process. It is expected that Lithuania's strategic documents following from EU strategic documents will help to guarantee the andragogue's role in the sphere of teachers' qualification development as well as other spheres of adult education. 